\title{
REVIEW
}

\section{Heart rate as a possible therapeutic guide for the prevention of cardiovascular disease}

\begin{abstract}
Taku Inoue ${ }^{1,2}$, Kunitoshi Iseki ${ }^{3}$ and Yusuke Ohya ${ }^{2}$
Epidemiologic evidence indicates that an elevated heart rate (HR) is an independent predictor of all-cause and cardiovascular (CV) mortality. Ivabradine, a pure HR-lowering agent, reduces $\mathrm{CV}$ events in patients with coronary artery disease (CAD) and chronic heart failure, and indicate that an HR greater than 70 b.p.m. is hazardous. These findings demonstrate not only that an elevated $\mathrm{HR}$ is an epiphenomenon of $\mathrm{CV}$ risk status but also that an elevated HR itself should be a therapeutic target. In addition, recent epidemiologic evidence demonstrates that the in-treatment HR or HR change predicts subsequent all-cause and CV mortality, independent of the HR-lowering strategy. Characteristics of the in-treatment HR or HR change are also important as possible therapeutic guides for risk management. However, there have been concerns regarding deleterious effects on $\mathrm{CV}$ event prevention owing to $\beta$-blocker-derived pharmacologic HR reduction. The potential role of HR and its modulation should be considered in future guidance documents.
\end{abstract}

Hypertension Research (2013) 36, 838-844; doi:10.1038/hr.2013.98; published online 22 August 2013

Keywords: $\beta$-blocker; cardiovascular disease; coronary artery disease; heart rate; mortality

\section{INTRODUCTION}

On the basis of extensive evidence from epidemiologic studies and clinical trials designed for other purposes, an elevated heart rate (HR; $>70$ b.p.m.) is an undesirable prognostic sign. The resting HR increases with an increase in temperature, fear, immobility and cardiometabolic risk, so physicians have considered an elevated HR to be an epiphenomenon representing 'poor conditioning. The BEAUTIFUL (morBiditymortality EvAlUaTion of the If inhibitor ivabradine in patients with coronary disease and left-ventricULar dysfunction) ${ }^{1}$ and SHIFT (systolic heart failure treatment with the If inhibitor ivabradine Trial) ${ }^{2}$ studies, however, prospectively evaluated the prognostic significance of lowering HR and demonstrated that HR should be a therapeutic target in patients with coronary artery disease (CAD) and chronic heart failure. Apart from patients with acute coronary syndrome and congestive heart failure, there are no reports regarding the optimal level of the resting $\mathrm{HR}$ in guidelines for the chronic care of patients with hypertension or stable CAD, for example. The importance of an elevated HR is therefore still not generally accepted in actual clinical practice. In this context, we summarize the clinical importance of $\mathrm{HR}$, especially from an epidemiologic point of view. Moreover, we discuss several of the clinical applications of in-treatment HR for improving patient prognosis.

\section{EPIDEMIOLOGIC EVIDENCE DEMONSTRATING HR AS A PROGNOSTIC FACTOR}

Numerous studies have demonstrated that the baseline HR is associated with all-cause and cardiovascular (CV) mortality for a wide spectrum of subjects among the general population, including patients with CV disease, such as hypertension, acute myocardial infarction and congestive heart failure. ${ }^{3}$ Further support derives from studies of patients with type 2 diabetes $^{4}$ and individuals undergoing hemodialysis. ${ }^{5-7}$ Iseki et al. ${ }^{7}$ examined the relationship between pulse rate and survival based on a nationwide hemodialysis registry. The authors demonstrated that the adjusted odds ratio for 1-year all-cause mortality was 1.20 (40-49 b.p.m.), 1.06 (50-59 b.p.m.), 1.13 (70-79 b.p.m.), 1.46 (80-89 b.p.m.), 1.91 (90-99 b.p.m.), 2.61 (100-109 b.p.m.) and 2.43 (110-129 b.p.m.) compared with the reference pulse rate (60-69 b.p.m.) (Figure 1). A recent evaluation of 2608 stable CAD patients indicated that an elevated $\mathrm{HR}$ is associated with $\mathrm{CV}$ events in diabetic but not non-diabetic patients. ${ }^{8}$

\section{Evidence of in-treatment $\mathrm{HR}$ as a prognostic factor}

Recent studies indicated that the in-treatment HR provides prognostic information beyond the baseline HR (Table 1). The NordTrøndelag County Health Study ${ }^{9}$ evaluated a general population of 29325 people and reported that the hazard ratio of death from ischemic heart disease in participants with a baseline HR of less than 70 but more than 85 b.p.m. at follow-up was 1.8-1.9 times greater compared with those with a HR of less than 70 b.p.m. at both baseline and follow-up. The Paris Prospective Study $1^{10}$ evaluated healthy male workers and demonstrated that an increase in the follow-up HR caused a $19 \%$ higher mortality risk (95\% confidence interval (CI): 4-37\%). Importantly, this study, but not the Nord-Trøndelag County Health Study, demonstrated that a decrease in the follow-up HR of at least 4 b.p.m. had a $14 \%$ lower mortality risk (relative risk: $0.86,95 \%$

${ }^{1}$ Center of Residency and Fellowship Program, University Hospital of the Ryukyus, Nishihara, Japan; ${ }^{2}$ Department of Cardiovascular Medicine, Nephrology and Neurology, Faculty of Medicine, University of the Ryukyus, Nishihara, Japan and ${ }^{3}$ Dialysis Unit, University Hospital of the Ryukyus, Nishihara, Japan 


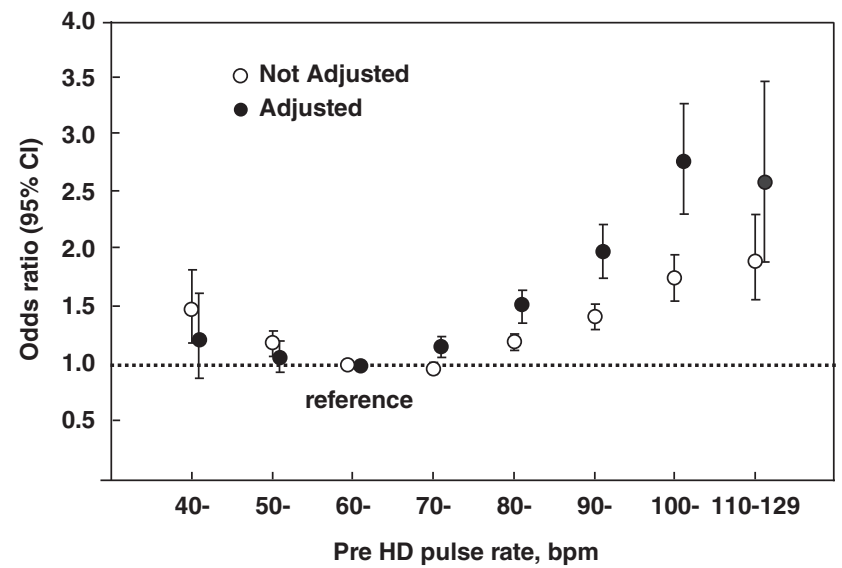

$\begin{array}{lllllllll}\text { N of death } & 93 & 641 & 2294 & 3298 & 1978 & 978 & 359 & 117\end{array}$

$\begin{array}{lllllllll}\text { N of patients } & 1068 & 9022 & 37466 & 56297 & 27607 & 11651 & 3525 & 1066\end{array}$

Figure 1 Odds ratio $(95 \% \mathrm{Cl})$ of death based on the pre-hemodialysis (HD) pulse rate. Patients with a pre-HD pulse rate of 60-69b.p.m. were used for comparison (reference). Reprinted with permission from Iseki et al. ${ }^{7}$
CI: 0.74-1.00). Paul et al. ${ }^{11}$ evaluated the relationship between HR change and all-cause and CV mortality risk in $\sim 4000$ hypertensive patients followed in the Glasgow Blood Pressure Clinic study. The authors demonstrated that a developing or persistent HR above 80 b.p.m. increases the risk of all-cause (hazard ratio: 1.78, 95\% CI: 1.31-2.41) and CV (hazard ratio: 1.92, 95\% CI: 1.24-2.99) mortality, even after adjusting for rate-limiting therapy. Moreover, patients whose HR increased at least 5 b.p.m. between baseline and their final clinic visit had a 51\% higher all-cause mortality risk (hazard ratio: 1.51, 95\% CI: 1.03-2.20). The LIFE study, in which CV and all-cause mortality were evaluated in hypertensive patients with ECGconfirmed left ventricular hypertrophy, yielded the same results. ${ }^{12} \mathrm{~A}$ similar increase in risk associated with a higher in-treatment $\mathrm{HR}$ in both losartan- and atenolol-based treatment indicated that atenololtreated patients did not have lower mortality. The association between the in-treatment HR and CV events was nearly the same as in other hypertensive studies, regardless of $\beta$-blocker use. ${ }^{13,14}$ In patients with stable CAD, an increased CV event risk was apparent in patients with a mean in-treatment HR greater than 75 b.p.m., and a J-shape relation was observed regardless of the therapeutic strategy ${ }^{15}$ (Figure 2). These results suggest that a serial assessment of HR can provide additional information about CV event risk.

Table 1 Studies demonstrating the association between in-treatment HR or serial HR change and adverse outcome

\begin{tabular}{|c|c|c|c|c|c|c|}
\hline \multirow[b]{2}{*}{ Study name } & \multirow[b]{2}{*}{ Patients } & \multirow[b]{2}{*}{ No. } & \multirow[b]{2}{*}{ Follow (years) } & \multicolumn{2}{|r|}{$H R$} & \multirow[b]{2}{*}{ Results } \\
\hline & & & & Baseline & In-treatment & \\
\hline $\begin{array}{l}\text { Nord-Trøndelag County } \\
\text { Health Study9 }\end{array}$ & $\begin{array}{l}\text { General } \\
\text { population }\end{array}$ & 29325 & 12 & NA & $\mathrm{N} / \mathrm{A}$ & $\begin{array}{l}\text { Total mortality } \\
\quad>85 \text { b.p.m. vs. < } 70 \text { b.p.m.: hazard ratio } 1.9,95 \% \mathrm{Cl} 1.0-3.6 \\
>85 \text { b.p.m. vs. } 70-85 \text { b.p.m.: hazard ratio } 1.8,95 \% \mathrm{Cl} 1.2-2.8\end{array}$ \\
\hline Paris Prospective Study $1^{10}$ & $\begin{array}{l}\text { General } \\
\text { population }\end{array}$ & 5139 & 23 & NA & N/A & $\begin{array}{l}\text { Total mortality of } \mathrm{HR} \text { decrease vs. no change: } \\
\text { RR } 0.86,95 \% \mathrm{Cl} 0.74-1.00 \\
\text { Total mortality of } \mathrm{HR} \text { increase vs. no change: } \\
\quad \text { RR } 1.19,95 \% \mathrm{Cl} 1.04-1.37\end{array}$ \\
\hline Glasgow BP Clinic study ${ }^{11}$ & Outpatient HT & 4065 & 2.5 & 77 & 74 & $\begin{array}{l}\text { Total mortality } \\
\text { Persistent }>80 \text { b.p.m. vs. persistent <60 b.p.m.: } \\
\text { hazard ratio } 1.78,95 \% \mathrm{Cl} 1.31-2.41 \\
\text { HR change at the end of follow-up }>5 \text { b.p.m. vs. }<-10 \text { b.p.m.: } \\
\text { hazard ratio } 1.51,95 \% \mathrm{Cl} 1.03-2.20\end{array}$ \\
\hline LIFE $^{12}$ & HT & 9190 & 4.8 & $\begin{array}{l}\text { At } \\
\text { Los }\end{array}$ & $\begin{array}{l}-4.1 \\
-0.5\end{array}$ & $\begin{array}{l}\text { Every } 10 \text { b.p.m. increment } \\
\text { CV mortality: hazard ratio } 1.16,95 \% \mathrm{Cl} 1.06-1.27 \\
\text { Total mortality: hazard ratio } 1.25,95 \% \mathrm{Cl} 1.17-1.33 \\
\text { Developing or persist } \geqslant 84 \text { b.p.m. } \\
\text { CV mortality; hazard ratio } 1.55,95 \% \mathrm{Cl} 1.16-2.05 \\
\text { Total mortality; hazard ratio } 1.79,95 \% \mathrm{Cl} 1.46-2.21\end{array}$ \\
\hline ASCOT-BPLA $^{13}$ & HT without CAD & 12759 & 3.8 & $\begin{array}{l}\text { At } 73.8 \\
\text { Am } 73.8\end{array}$ & $\begin{array}{c}-12.0 \\
-1.3\end{array}$ & $\begin{array}{l}\mathrm{HR} \text { at } 6 \text { weeks was associated with the nonfatal MI } \\
\text { and fatal } \mathrm{CHD} \text { outcome. }\end{array}$ \\
\hline ONTARGET/TRANSCEDENT ${ }^{14}$ & High-risk HT & 31531 & 5 & 68.0 & $\mathrm{~N} / \mathrm{A}$ & $\begin{array}{l}\text { Every } 10 \text { b.p.m. increment } \\
\text { Total mortality: hazard ratio } 1.35,95 \% \mathrm{Cl} 1.30-1.40 \\
\text { CV mortality: hazard ratio } 1.36,95 \% \mathrm{Cl} 1.32-1.45 \\
\text { MCE: hazard ratio } 1.26,95 \% \mathrm{Cl} 1.22-1.30 \\
\text { MI: hazard ratio } 1.03,95 \% \mathrm{Cl} 0.97-1.03 \\
\text { Stroke: hazard ratio } 1.17,95 \% \mathrm{Cl} 1.10-1.25\end{array}$ \\
\hline INVEST15 & CAD with $\mathrm{HT}$ & 22576 & 2.7 & $\begin{array}{l}75.7 \\
75.7\end{array}$ & $\begin{array}{l}69.2 \\
72.8\end{array}$ & $\begin{array}{l}\text { No adverse outcome difference between the drugs. } \\
\text { CV event risk was apparent in patients with HR }>75 \text { b.p.m. } \\
\text { J-shape HR and events relation was observed. }\end{array}$ \\
\hline
\end{tabular}

Abbreviations: ASCOT-BPLA, Anglo-Scandinavian Cardiac Outcomes Trial Blood Pressure-Lowering Arm; b.p.m., beats per minute; BP, blood pressure; CAD, coronary artery disease; Cl, confidence interval; CV, cardiovascular; HR, heart rate; HT, hypertension; INVEST, International Verapamil SR/Trandolapril Study; MI, myocardial infarction; MCE, major cardiovascular events; NA, not available; At, Atenorol; Los, Losaltan; Am, Amlodipine; ONTARGET, The Ongoing Telmisartan Alone and in Combination with Ramipril Global Endpoint Trial; TRANSCEDENT, The Telmisartan available; At, Atenorol; LOS, Losaltan; Am, Amlodipine; ONTARGET, The Ongoing Telmis
Randomised AssessmeNt Study in ACE iNtolerant subjects with cardiovascular Disease. 


\section{EVIDENCE DEMONSTRATING THE ASSOCIATION BETWEEN HR AND CV RISK AND TARGET ORGAN DAMAGE}

Individuals with tachycardia often have characteristic features of insulin resistance syndrome, including high blood pressure, obesity, increased blood glucose and insulin levels, and an abnormal lipid profile. ${ }^{16,17}$ An elevated HR not only coexists with these cardiometabolic risks but also can precede these cardiometabolic abnormalities, ${ }^{18,19}$ indicating that HR is not merely an epiphenomenon of patient risk status. We examined the relationship between HR and cardiometabolic risk in $\sim 10000$ healthy individuals and demonstrated that an elevated HR was independently associated with cardiometabolic risk clustering ${ }^{17}$ and developing metabolic syndrome. ${ }^{18}$ The elevated $\mathrm{HR}$ and sympathetic overactivation found in masked hypertension and white-coat hypertension are also consistent with this finding. ${ }^{20,21}$ Multiple exaggerated spikes in postprandial blood glucose, free-fatty acids and triglycerides induced by the excessive intake of a high-calorie diet generate free radicals and trigger biochemical cascades of nitric oxide degeneration, inflammation, endothelial dysfunction, sympathoexcitation, parasympathetic depression and concurrent HR elevation. ${ }^{22,23}$ These findings indicate that a lifestyle-induced increase in sympathetic drive may promote these cardiometabolic changes.

An elevated HR is also associated with target organ damage. In patients with high-risk hypertension, an elevated HR is an independent predictor of microalbuminuria. ${ }^{24}$ We evaluated a total of 6759 healthy subjects and demonstrated that subjects with an elevated HR are likely to develop proteinuria in middle-aged or older. ${ }^{25}$ Benetos et al. ${ }^{26}$ found that an elevated $\mathrm{HR}$ is one of the most powerful predictors of the accelerated progression of arterial stiffness, as assessed by pulse-wave velocity.

\section{EVIDENCE OF PHARMACOLOGIC HR LOWERING AND OUTCOME}

Patients with chronic heart failure and acute myocardial infarction Certain drug categories used for $\mathrm{CV}$ disease, for example, $\beta$-blockers and non-dihydropyridine calcium channel blockers, lower HR. Mortality reduction is evident with pharmacologic HR lowering in patients with chronic heart failure and acute myocardial infarction. ${ }^{27,28}$ The reduction in HR is linearly related to mortality in this spectrum of subjects.
Ivabradine, which specifically acts on the sino-atrial node by inhibiting the $\mathrm{I}_{\mathrm{f}}$ current of cardiac pacemaker cells, without affecting other cardiac ionic currents, recently became available. The $\mathrm{I}_{\mathrm{f}}$ current, which goes through the $\mathrm{I}_{\mathrm{f}}$ channel, is an important ionic current involved in the pacemaker activity of the sino-atrial node cells. ${ }^{29}$ The degree of activation of the $\mathrm{I}_{\mathrm{f}}$ channel determines the velocity of diastolic depolarization and thus determines the time at which the threshold for the initiation of an action potential is reached. Ivabradine specifically binds to the $\mathrm{I}_{\mathrm{f}}$ channel and reduces the slope of spontaneous diastolic depolarization in these cells, without other hemodynamic effects. ${ }^{30}$ This drug does not bind to calcium channels, muscarinic acetylcholine receptors, or $\beta$ receptors. Studies using this characteristic drug reinforced the clinical significance of lowering HR. BEAUTIFUL ${ }^{31}$ evaluated whether lowering HR with ivabradine reduced CV death and morbidity in $\mathrm{CAD}$ patients with left ventricular systolic dysfunction. Lowering HR, but not ivabradine use itself, improved the outcomes of CAD in a subgroup of patients with an HR of at least 70 b.p.m. (Figure 3). SHIFT $^{2}$ evaluated the effect of $\mathrm{HR}$ lowering on $\mathrm{CV}$ mortality and hospital admission for worsening heart failure in patients with symptomatic chronic heart failure with guideline-based heart failure therapy. The in-treatment HR was directly associated with the subsequent CV outcome. Patients with an HR lower than 60 b.p.m. on treatment had fewer CV events than patients with a higher HR. The effect of ivabradine is accounted for by the HR reduction (Figure 4). These results indicated that HR per se should be a therapeutic target.

\section{Patients with stable CAD}

Few clinical studies have demonstrated the effects of lowering HR in patients with stable CAD (Table 2). In the ASIST (Atenolol Silent Ischemia Study), atenolol reduced HR from 75 b.p.m. to 63 b.p.m., resulting in a reduction in CV events and other adverse events compared with placebo. ${ }^{32}$ The BIP (Bezafibrate Infarction Prevention) study examined 2723 patients with diabetic $\mathrm{CAD}$ and demonstrated that $\beta$-blocker therapy is associated with a $42 \%$ reduction in total mortality (95\% CI: $0.44-0.77)$ and a $34 \%$ reduction in cardiac mortality (95\% CI: $0.46-0.96)$ compared with non- $\beta$ blockers. ${ }^{33}$ The TIBBS (Total Ischemic Burden Bisoprolol Study) compared the prognostic significance of bisoprolol and a sustained-release formulation of nifedipine and demonstrated that $\mathrm{CV}$ event rates were significantly lower in the

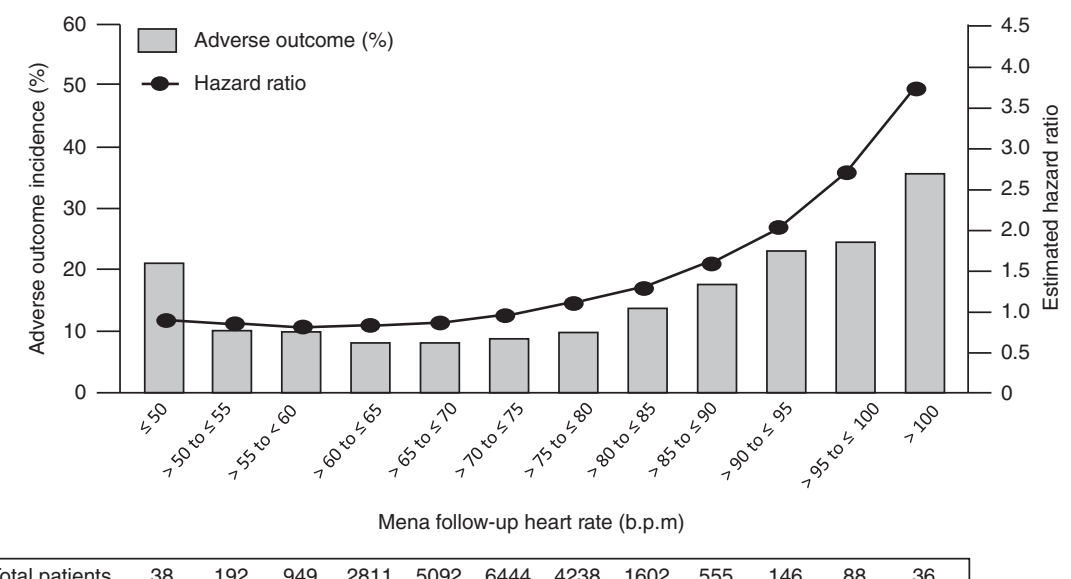

Figure 2 Relationship between in-treatment HR for INVEST (International Verapamil SR/Trandolapril Study) patients and incidence of adverse outcomes (left axis, bars) and risk (right axis - -, hazard ratio) derived from a stepwise Cox proportional hazards model. The nadir for in-treatment HR was 59 b.p.m. Reprinted with permission from Kolloch et al. ${ }^{15}$ 


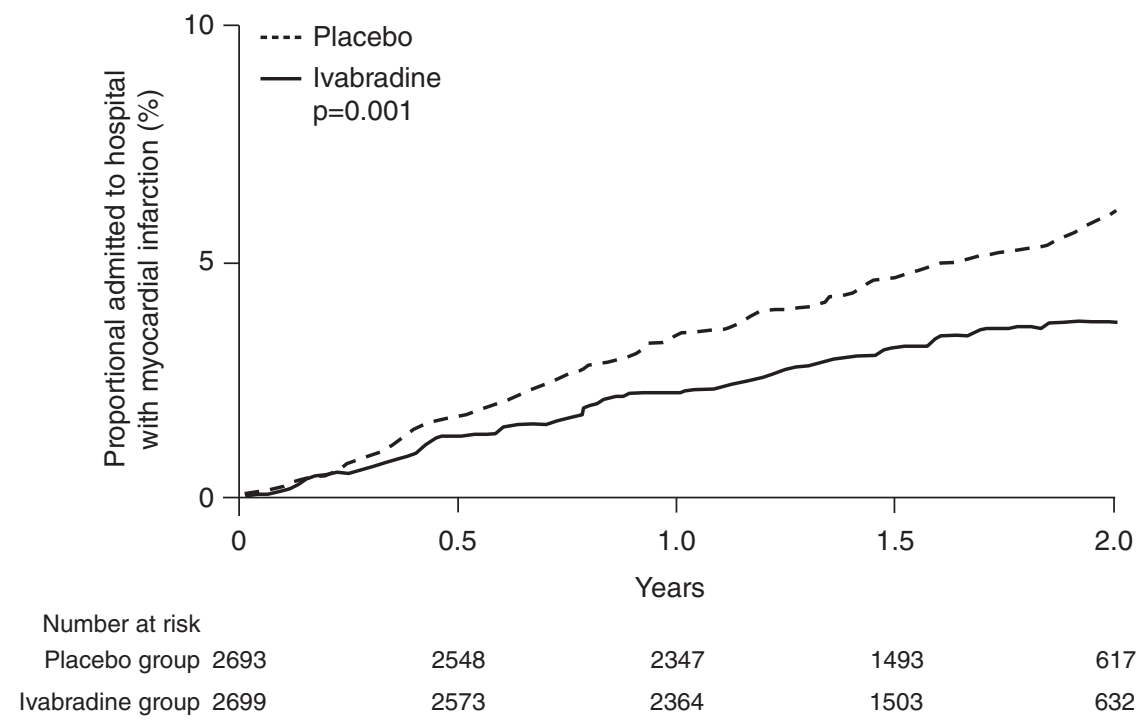

Figure 3 Kaplan-Meier time-to-event plots, by treatment group in a prespecified subgroup with HR of 70 b.p.m. or greater for secondary endpoints of admission to hospital for acute myocardial infarction in BEAUTIFUL. Reprinted with permission from Fox et al. ${ }^{31}$

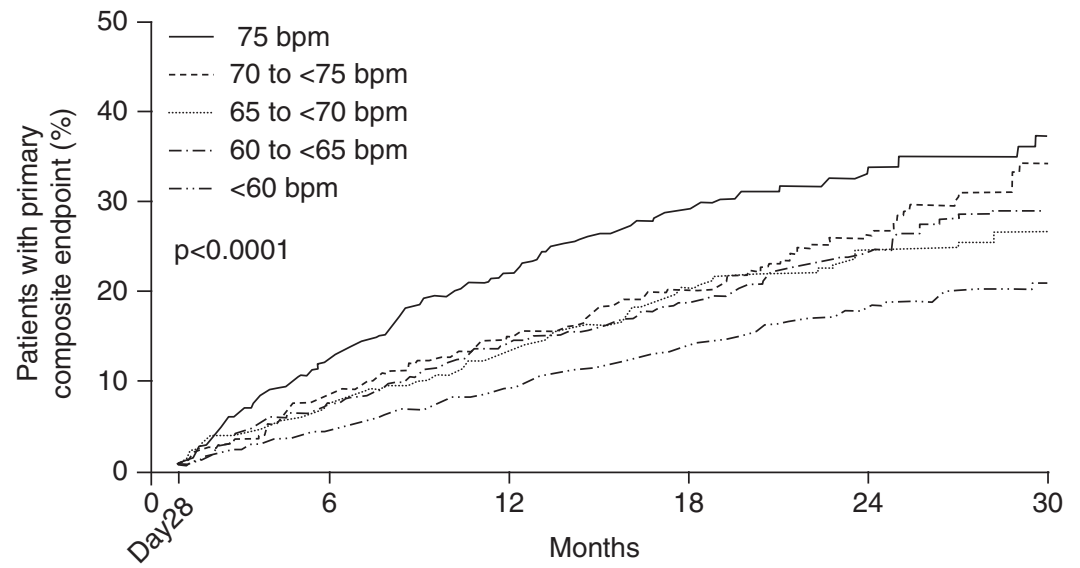

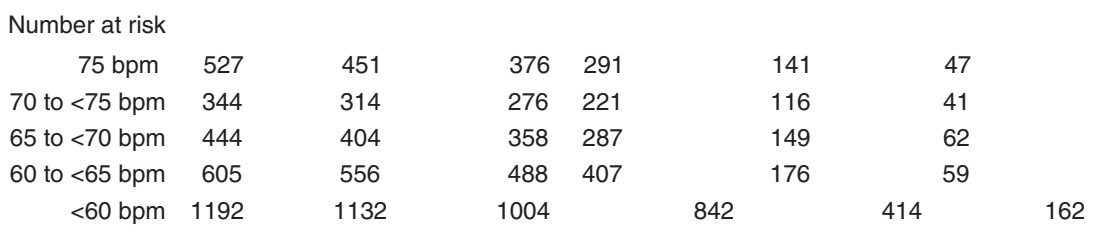

Figure 4 Kaplan-Meier cumulative event curves for CV death or hospital admission for worsening heart failure in the ivabradine group, according to groups defined by HR achieved at 28 days in the SHIFT (Self-Harm Intervention, Family Therapy). Reprinted with permission from Bohm et al. ${ }^{2}$

bisoprolol group compared with the nifedipine group (22 vs. 31\%, $P=0.033){ }^{34}$ The TIBET (Total Ischaemic Burden European Trial), ${ }^{35}$ however, showed no advantage for atenolol other than a greater HR reduction, probably owing to the significant high withdrawal rate $(27 \%$ for atenolol, $40 \%$ for nifedipine and $29 \%$ for combined use). The APSIS (Angina Prognosis Study in Stockholm) ${ }^{36}$ and INVEST (International Verapamil SR/Trandolapril Study) ${ }^{15}$ compared the prognostic effects of $\beta$-blockers (atenolol or metoprolol) and a HR-lowering calcium channel blocker (verapamil) and found no significant prognostic difference between the two therapeutic strategies. INVEST, however, reported that the in-treatment HR is associated with patient prognosis and increases in the mean follow-up resting HR from 70 to 80 b.p.m. are associated with a $31 \%$ increased risk of adverse outcomes. ${ }^{15}$
A real-world, large, contemporary database of stable CAD patients described an in-treatment HR of 68.3 b.p.m., and $75.1 \%$ of them were prescribed $\beta$-blockers. ${ }^{37}$ Among the patients using $\beta$-blockers, $41.1 \%$ had a mean HR above 70 b.p.m., which was selected on the basis of the results of several studies to be an important prognostic threshold. ${ }^{14,31,38}$

\section{Patients with uncomplicated hypertension}

Hypertension is the leading cause of CVD, and blood pressure lowering is therefore the primary goal for patients with hypertension. There are several reports demonstrating that $\beta$-blockers do not improve the prognosis of patients with hypertension. ${ }^{39,40}$ Bangalore et $a .^{41}$ demonstrated in their meta-regression analysis that HR 
Table 2 Studies demonstrating the association between rate-limiting therapy using $\beta$-blocking agents and the prognosis of patients with stable CAD. The effect of risk reduction using $\beta$-blocking agents are shown in the table

\begin{tabular}{|c|c|c|c|c|c|c|c|}
\hline \multirow[b]{2}{*}{ Study name } & \multirow[b]{2}{*}{ Patients } & \multirow[b]{2}{*}{ No. } & \multirow[b]{2}{*}{ Follow (years) } & \multirow[b]{2}{*}{ Drug } & \multicolumn{2}{|c|}{$H R$} & \multirow[b]{2}{*}{ Results } \\
\hline & & & & & Baseline & In-treatment & \\
\hline \multirow[t]{3}{*}{$\mathrm{ASIST}^{32}$} & Silent ischemia & 306 & 0.9 & Ate Pla & 75 & 63 & All-cause death and CV events: RR $0.55,95 \% \mathrm{Cl} 0.22-1.33$ \\
\hline & & & & & 75 & 75 & Aggravation of angina: RR $0.35,95 \% \mathrm{Cl} 0.17-0.72$ \\
\hline & & & & & & & Adverse outcome: RR $0.44,95 \% \mathrm{Cl} 0.26-0.75$ \\
\hline \multirow[t]{2}{*}{$\mathrm{BIP} 33$} & DM with $C A D$ & 2723 & 3 & BB & 70 & N/A & Total mortality: RR $0.58,95 \% \mathrm{Cl} 0.44-0.77$ \\
\hline & & & & Non BB & 75 & $\mathrm{~N} / \mathrm{A}$ & Cardiac mortality: RR $0.66,95 \% \mathrm{Cl} 0.46-0.94$ \\
\hline \multirow[t]{2}{*}{$\mathrm{TIBBs}^{34}$} & Stable CAD & 317 & 1 & Bis & 74.2 & $\mathrm{~N} / \mathrm{A}$ & CV events rate: \\
\hline & & & & Nif & 74.0 & $\mathrm{~N} / \mathrm{A}$ & Bis $22.1 \%$ vs. Nif $33.1 \%, P=0.033$ \\
\hline \multirow[t]{3}{*}{$\mathrm{TIBET}^{35}$} & Stable CAD & 682 & 2 & Ate & $\mathrm{N} / \mathrm{A}$ & -15.4 & No difference in adverse outcome among the strategies \\
\hline & & & & Nif & $\mathrm{N} / \mathrm{A}$ & +2.9 & \\
\hline & & & & Com & N/A & -13.5 & \\
\hline \multirow[t]{2}{*}{ APSIS $^{36}$} & Stable CAD & 809 & 3.4 & Met & $\mathrm{N} / \mathrm{A}$ & N/A & All-cause death: OR $0.94,95 \% \mathrm{Cl} 0.53-1.67$ \\
\hline & & & & Ver & N/A & $\mathrm{N} / \mathrm{A}$ & All-cause death and CV events: OR $1.22,95 \% \mathrm{Cl} 0.95-1.56$ \\
\hline \multirow[t]{2}{*}{ INVEST $^{15}$} & Stable CAD & 22576 & 2.7 & Ate & 75.6 & 69.2 & No adverse outcome difference between the drugs. \\
\hline & & & & Ver & 75.5 & 72.8 & $\begin{array}{l}\text { CV event risk was apparent in patients with } \mathrm{HR}>75 \text { b.p.m. } \\
\text { J-shape HR and event relation were observed. }\end{array}$ \\
\hline
\end{tabular}

Abbreviations: ASIST, Atenolol Silent Ischemia Study; APSIS, Angina Prognosis Study in Stockholm; Ate, atenolol; BB, $\beta$-blocker; BIP, Bezafibrate Infarction Prevention; Bis, bisoprolol; CAD, coronary artery disease; Cl, confidence interval; Com, combination; CV, cardiovascular; DM, diabetes mellitus; IHD, ischemic heart disease; INVEST, International Verapamil SR/Trandolapril Study; Met, metoprolol; MI, myocardial infarction; N/A, not available; Nif, nifedipine; NS, not significant; Pla, placebo; RR, relative risk; TIBET, Total Ischaemic Burden European Trial; TIBBs,

Total Ischemic Burden Bisoprolol Study; Ver, verapamil.

lowering using a $\beta$-blocker increased the risk of a CV event in patients with hypertension. Their results, however, should be cautiously interpreted. The blood pressure of the $\beta$-blocker group was at most $9.2 \mathrm{~mm} \mathrm{Hg}$ higher than that of most patients in the active control group. Accordingly, their result simply indicated that $\beta$-blockers are inferior to other drugs for blood pressure lowering. In the CAFÉ (Conduit Artery Functional Endpoint) study, an increase in central aortic pressure owing to HR lowering might have been the cause of increased $\mathrm{CV}$ events in a $\beta$-blocker-based strategy. ${ }^{42}$ In the ASCOT-BPLA (Anglo-Scandinavian Cardiac Outcomes Trial Blood Pressure-Lowering Arm) study, however, the SBP difference of $2.7 \mathrm{~mm} \mathrm{Hg}$ between the $\beta$-blocker- and amlodipine-based regimens could explain the risk of stroke. ${ }^{43}$ Moreover, the ASCOT-BPLA study demonstrated that the HR at 6 weeks was associated with nonfatal myocardial infarction and a fatal CHD outcome. ${ }^{13}$

\section{HR AS A POSSIBLE THERAPEUTIC GUIDE}

An elevated HR represents sympathetic overactivation and is comorbid with 'poor conditioning', such as cardiometabolic risks and target organ damage. It is logically plausible that in-treatment HR reduction leads to a better prognosis. ${ }^{10,11}$ In fact, non-pharmacologic HRlowering strategies, such as dietary supplementation with omega-3 fatty acids, ${ }^{44}$ docosahexaenoic acid use, ${ }^{45}$ exercise training, ${ }^{46}$ body weight reduction ${ }^{47,48}$ and lipid lowering by HMG-CoA (3-hydroxy-3methyl coenzyme A) reductase inhibitors, ${ }^{49}$ also reduce HR and lead to favorable outcomes. A serial assessment of HR in addition to the baseline HR may provide additional information about subsequent $\mathrm{CV}$ event risk. The in-treatment HR and decreases in HR can be used as possible therapeutic guides.

The resting HR is an established index for predicting the short- and medium-term prognoses of patients with acute coronary syndromes, and several risk scales have been developed. ${ }^{50-54}$ Despite numerous epidemiologic studies, HR is not being used as an indicator of risk management in patients with hypertension and stable CAD who are often treated in actual medical practice. A resting HR of 70 b.p.m. is a critical prognostic threshold that is based on the results of several studies on patients with stable CAD. ${ }^{14,31,38}$ In the COURAGE (Clinical Outcomes Utilizing Revascularization and Aggressive Drug Evaluation) trial, ${ }^{55}$ optimal medical therapy included $\beta$-blockers and antiplatelet use in addition to a combined intensive reduction in blood pressure and serum lipid levels. Taking the 'optimal HR level' into account might be a therapeutic option and might contribute to reducing residual risk..$^{56}$

HR is a ready-to-use, cost-effective biomarker. HR-guided patient care, in addition to the control of other cardiometabolic risk factors, contributes to a better prognosis for the prevention of $\mathrm{CV}$ events. Attention should be paid to the further evaluation of patients with a developing or persistent elevated HR during medication to identify possible underlying abnormalities.

\section{CONCLUSION}

HR is an independent predictor of all-cause and CV mortality. As HR is a target for the prevention of CV events, the clinical importance of $\mathrm{HR}$ as a therapeutic guide should be emphasized. HR-guided patient care allows for ready-to-use, cost-effective, CV risk reduction.

\section{CONFLICT OF INTEREST}

The authors declare no conflict of interest.

1 Fox K, Ford I, Steg PG, Tendera M, Robertson M, Ferrari R. Heart rate as a prognostic risk factor in patients with coronary artery disease and left-ventricular systolic dysfunction (BEAUTIFUL): a subgroup analysis of a randomised controlled trial. Lancet 2008; 372: 817-821.

2 Bohm M, Swedberg K, Komajda M, Borer JS, Ford I, Dubost-Brama A, Lerebours G, Tavazzi L. Heart rate as a risk factor in chronic heart failure (SHIFT): the association between heart rate and outcomes in a randomised placebo-controlled trial. Lancet 2010; 376: 886-894.

3 Palatini P. Elevated heart rate in cardiovascular diseases: a target for treatment? Prog Cardiovasc Dis 2009; 52: 46-60. 
4 Linnemann B, Janka HU. Prolonged QTc interval and elevated heart rate identify the type 2 diabetic patient at high risk for cardiovascular death. The Bremen Diabetes Study. Exp Clin Endocrinol Diabetes 2003; 111: 215-222.

5 Cice G, Di Benedetto A, D'Andrea A, D'Isa S, De Gregorio P, Marcelli D, Gatti E, Calabro R. Heart rate as independent prognostic factor for mortality in normotensive hemodialysed patients. J Nephrol 2008; 21: 704-712.

6 Inoue T, Tokuyama K, Yoshi S, Nagayoshi N, Iseki C, Iseki K. Elevated resting heart rate is an independent predictor of all-cause death and cardiovascular events in Japanese ambulatory hemodialysis patients. Clin Exp Nephrol 2012; 16: 938-944.

7 Iseki K, Nakai S, Yamagata K, Tsubakihara Y. Tachycardia as a predictor of poor survival in chronic haemodialysis patients. Nephrol Dial Transplant 2011; 26: 963-969.

8 Anselmino M, Ohrvik J, Ryden L. Resting heart rate in patients with stable coronary artery disease and diabetes: a report from the euro heart survey on diabetes and the heart. Eur Heart J 2010; 31: 3040-3045.

9 Nauman J, Janszky I, Vatten LJ, Wisloff U. Temporal changes in resting heart rate and deaths from ischemic heart disease. JAMA 2011; 306: 2579-2587.

10 Jouven X, Empana JP, Escolano S, Buyck JF, Tafflet M, Desnos M, Ducimetiere P. Relation of heart rate at rest and long-term ( $>20$ years) death rate in initially healthy middle-aged men. Am J Cardiol 2009; 103: 279-283.

11 Paul L, Hastie CE, Li WS, Harrow C, Muir S, Connell JM, Dominiczak AF, McInnes GT, Padmanabhan S. Resting heart rate pattern during follow-up and mortality in hypertensive patients. Hypertension 2010; 55: 567-574.

12 Okin PM, Kjeldsen SE, Julius S, Hille DA, Dahlof B, Edelman JM, Devereux RB. Allcause and cardiovascular mortality in relation to changing heart rate during treatment of hypertensive patients with electrocardiographic left ventricular hypertrophy. Eur Heart J 2010; 31: 2271-2279.

13 Poulter NR, Dobson JE, Sever PS, Dahlof B, Wedel H, Campbell NR. Baseline heart rate, antihypertensive treatment, and prevention of cardiovascular outcomes in ASCOT (Anglo-Scandinavian Cardiac Outcomes Trial). J Am Coll Cardiol 2009; 54: 1154-1161.

14 Rambihar S, Gao P, Teo K, Bohm M, Yusuf S, Lonn E. Heart rate is associated with increased risk of major cardiovascular events, cardiovascular and all-cause death in patients with stable chronic cardiovascular disease-An analysis of ONTARGET/ TRANSCEND. Circulation 2010; 122: A12667.

15 Kolloch R, Legler UF, Champion A, Cooper-Dehoff RM, Handberg E, Zhou Q, Pepine CJ. Impact of resting heart rate on outcomes in hypertensive patients with coronary artery disease: findings from the International Verapamil-sr/Trandolapril Study (INVEST). Eur Heart J 2008; 29: 1327-1334.

16 Palatini P, Julius S. Heart rate and the cardiovascular risk. J Hypertens 1997; 15: $3-17$

17 Inoue T, Oshiro S, Iseki K, Tozawa M, Touma T, Ikemiya Y, Takishita S. High heart rate relates to clustering of cardiovascular risk factors in a screened cohort. Jpn Circ J 2001; 65: 969-973.

18 Inoue T, Iseki K, Iseki C, Ohya Y, Kinjo K, Takishita S. Effect of heart rate on the risk of developing metabolic syndrome. Hypertens Res 2009; 32: 801-806.

19 Shigetoh Y, Adachi H, Yamagishi S, Enomoto M, Fukami A, Otsuka M, Kumagae S, Furuki K, Nanjo Y, Imaizumi T. Higher heart rate may predispose to obesity and diabetes mellitus: 20-year prospective study in a general population. Am J Hypertens 2009; 22: 151-155.

20 Ben-Dov IZ, Ben-Arie L, Mekler J, Bursztyn M. In clinical practice, masked hypertension is as common as isolated clinic hypertension: predominance of younger men. Am J Hypertens 2005; 18: 589-593.

21 Grassi G, Seravalle G, Trevano FQ, Dell'oro R, Bolla G, Cuspidi C, Arenare F, Mancia G. Neurogenic abnormalities in masked hypertension. Hypertension 2007, 50: 537-542.

22 Danson EJ, Li D, Wang L, Dawson TA, Paterson DJ. Targeting cardiac sympatho-vagal imbalance using gene transfer of nitric oxide synthase. J Mol Cell Cardiol 2009; 46 482-489.

23 Weissman A, Lowenstein L, Peleg A, Thaler I, Zimmer EZ. Power spectral analysis of heart rate variability during the 100 -g oral glucose tolerance test in pregnant women. Diabetes Care 2006; 29: 571-574.

24 Bohm M, Reil JC, Danchin N, Thoenes M, Bramlage P, Volpe M. Association of heart rate with microalbuminuria in cardiovascular risk patients: data from I-SEARCH. J Hypertens 2008; 26: 18-25.

25 Inoue T, Iseki K, Iseki C, Ohya Y, Kinjo K, Takishita S. Heart rate as a risk factor for developing chronic kidney disease: Iongitudinal analysis of a screened cohort. Clin Exp Nephrol 2009; 13: 487-493.

26 Benetos A, Adamopoulos C, Bureau JM, Temmar M, Labat C, Bean K, Thomas F, Pannier B, Asmar R, Zureik M, Safar M, Guize L. Determinants of accelerated progression of arterial stiffness in normotensive subjects and in treated hypertensive subjects over a 6-year period. Circulation 2002; 105: 1202-1207.

27 Kjekshus J, Gullestad L. Heart rate as a therapeutic target in heart failure. Eur Heart $J$ Supp/ 1999; 1: H64-H69.

28 Cucherat M. Quantitative relationship between resting heart rate reduction and magnitude of clinical benefits in post-myocardial infarction: a meta-regression of randomized clinical trials. Eur Heart J 2007; 28: 3012-3019.

29 Difrancesco D. Funny channels in the control of cardiac rhythm and mode of action of selective blockers. Pharmacol Res 2006; 53: 399-406.

30 Heusch G. Heart rate in the pathophysiology of coronary blood flow and myocardial ischaemia: benefit from selective bradycardic agents. $\mathrm{Br} J$ Pharmacol 2008; 153: 1589-1601
31 Fox K, Ford I, Steg PG, Tendera M, Ferrari R. Ivabradine for patients with stable coronary artery disease and left-ventricular systolic dysfunction (BEAUTIFUL): a randomised, double-blind, placebo-controlled trial. Lancet 2008; 372: 807-816.

32 Pepine CJ, Cohn PF, Deedwania PC, Gibson RS, Handberg E, Hill JA, Miller E, Marks $\mathrm{RG}$, Thadani U. Effects of treatment on outcome in mildly symptomatic patients with ischemia during daily life. The Atenolol Silent Ischemia Study (ASIST). Circulation 1994; 90: 762-768

33 Jonas M, Reicher-Reiss H, Boyko V, Shotan A, Mandelzweig L, Goldbourt U, Behar S. Usefulness of beta-blocker therapy in patients with non-insulin-dependent diabetes mellitus and coronary artery disease. Bezafibrate Infarction Prevention (BIP) Study Group. Am J Cardiol 1996; 77: 1273-1277.

34 Von Arnim T. Prognostic significance of transient ischemic episodes: response to treatment shows improved prognosis. Results of the Total Ischemic Burden Bisoprolol Study (TIBBs) follow-up. J Am Coll Cardiol 1996; 28: 20-24.

35 Dargie HJ, Ford I, Fox KM, Total Ischaemic Burden European Trial (TIBET). Effects of ischaemia and treatment with atenolol, nifedipine SR and their combination on outcome in patients with chronic stable angina. The TIBET Study Group. Eur Heart $J$ 1996; 17: 104-112.

36 Rehnqvist N, Hjemdahl P, Billing E, Bjorkander I, Eriksson SV, Forslund L, Held C, Nasman $\mathrm{P}$, Wallen NH. Effects of metoprolol vs verapamil in patients with stable angina pectoris. The Angina Prognosis Study in Stockholm (APSIS). Eur Heart J 1996; 17: 76-81.

37 Steg PG, Ferrari R, Ford I, Greenlaw N, Tardif JC, Tendera M, Abergel H, Fox KM. Heart rate and use of beta-blockers in stable outpatients with coronary artery disease. PLoS One 2012; 7: e36284.

38 Ho JE, Bittner V, Demicco DA, Breazna A, Deedwania PC, Waters DD. Usefulness of heart rate at rest as a predictor of mortality, hospitalization for heart failure, myocardial infarction, and stroke in patients with stable coronary heart disease (Data from the Treating to New Targets [TNT] trial). Am J Cardiol 2010; 105: 905-911.

39 Bangalore S, Wild D, Parkar S, Kukin M, Messerli FH. Beta-blockers for primary prevention of heart failure in patients with hypertension insights from a meta-analysis. J Am Coll Cardiol 2008; 52: 1062-1072.

40 Wiysonge C, Bradley H, Mayosi B, Maroney R, Mbewu A, Opie L, Volmink J. Beta-blockers for hypertension. Cochrane database of systematic reviews 2009, update of 2007, http://onlinelibrary.wiley.com/doi/10.1002/14651858.CD002003.pub2/abstract

41 Bangalore S, Sawhney S, Messerli FH. Relation of beta-blocker-induced heart rate lowering and cardioprotection in hypertension. J Am Coll Cardiol 2008; 52: 1482-1489.

42 Williams B, Lacy PS, Thom SM, Cruickshank K, Stanton A, Collier D, Hughes AD, Thurston H, O'Rourke M. Differential impact of blood pressure-lowering drugs on central aortic pressure and clinical outcomes: principal results of the Conduit Artery Function Evaluation (CAFE) study. Circulation 2006; 113: 1213-1225.

43 Turnbull F. Effects of different blood-pressure-lowering regimens on major cardiovascular events: results of prospectively-designed overviews of randomised trials. Lancet 2003; 362: 1527-1535.

44 Marik PE, Varon J. Omega-3 dietary supplements and the risk of cardiovascular events: a systematic review. Clin Cardiol 2009; 32: 365-372.

45 Mori TA, Bao DQ, Burke V, Puddey IB, Beilin LJ. Docosahexaenoic acid but not eicosapentaenoic acid lowers ambulatory blood pressure and heart rate in humans. Hypertension 1999; 34: 253-260.

46 Hambrecht R, Walther C, Mobius-Winkler S, Gielen S, Linke A, Conradi K, Erbs S, Kluge R, Kendziorra K, Sabri O, Sick P, Schuler G. Percutaneous coronary angioplasty compared with exercise training in patients with stable coronary artery disease: a randomized trial. Circulation 2004; 109: 1371-1378.

47 Grassi G, Seravalle G, Colombo M, Bolla G, Cattaneo BM, Cavagnini F, Mancia G. Body weight reduction, sympathetic nerve traffic, and arterial baroreflex in obese normotensive humans. Circulation 1998; 97: 2037-2042.

48 Straznicky NE, Lambert GW, McGrane MT, Masuo K, Dawood T, Nestel PJ, Eikelis N, Schlaich MP, Esler MD, Socratous F, Chopra R, Lambert EA. Weight loss may reverse blunted sympathetic neural responsiveness to glucose ingestion in obese subjects with metabolic syndrome. Diabetes 2009; 58: 1126-1132.

49 Welzig CM, Shin DG, Park HJ, Kim YJ, Saul JP, Galper JB. Lipid lowering by pravastatin increases parasympathetic modulation of heart rate: Galpha(i2), a possible molecular marker for parasympathetic responsiveness. Circulation 2003; 108: 2743-2746.

50 Eagle KA, Lim MJ, Dabbous OH, Pieper KS, Goldberg RJ, Van de Werf F, Goodman SG, Granger CB, Steg PG, Gore JM, Budaj A, Avezum A, Flather MD, Fox KA. A validated prediction model for all forms of acute coronary syndrome: estimating the risk of 6-month postdischarge death in an international registry. JAMA 2004; 291: 2727-2733.

51 Marchioli R, Avanzini F, Barzi F, Chieffo C, Di Castelnuovo A, Franzosi MG, Geraci E, Maggioni AP, Marfisi RM, Mininni N, Nicolosi GL, Santini M, Schweiger C, Tavazzi L, Tognoni G, Valagussa F. Assessment of absolute risk of death after myocardial infarction by use of multiple-risk-factor assessment equations: GISSI-Prevenzione mortality risk chart. Eur Heart J 2001; 22: 2085-2103.

52 Morrow DA, Antman EM, Charlesworth A, Cairns R, Murphy SA, de Lemos JA Giugliano RP, McCabe CH, Braunwald E. TIMI risk score for ST-elevation myocardial infarction: A convenient, bedside, clinical score for risk assessment at presentation: An intravenous nPA for treatment of infarcting myocardium early II trial substudy. Circulation 2000; 102: 2031-2037.

53 Morrow DA, Antman EM, Giugliano RP, Cairns R, Charlesworth A, Murphy SA, de Lemos JA, McCabe $\mathrm{CH}$, Braunwald $\mathrm{E}$. A simple risk index for rapid initial triage of patients with ST-elevation myocardial infarction: an InTIME II substudy. Lancet 2001; 358: 1571-1575 
54 Wiviott SD, Morrow DA, Frederick PD, Giugliano RP, Gibson CM, McCabe CH Cannon CP, Antman EM, Braunwald E. Performance of the thrombolysis in myocardial infarction risk index in the National Registry of Myocardial Infarction-3 and -4: a simple index that predicts mortality in ST-segment elevation myocardial infarction. J Am Coll Cardiol 2004; 44: 783-789.

55 Boden WE, O'Rourke RA, Teo KK, Hartigan PM, Maron DJ, Kostuk WJ, Knudtson M, Dada M, Casperson P, Harris CL, Chaitman BR, Shaw L, Gosselin G, Nawaz S, Title LM, Gau G, Blaustein AS, Booth DC, Bates ER, Spertus JA, Berman DS, Mancini GB,
Weintraub WS. Optimal medical therapy with or without $\mathrm{PCl}$ for stable coronary disease. N Engl J Med 2007; 356: 1503-1516.

56 Fruchart JC, Sacks FM, Hermans MP, Assmann G, Brown WV, Ceska R, Chapman MJ, Dodson PM, Fioretto P, Ginsberg HN, Kadowaki T, Lablanche JM Marx N, Plutzky J, Reiner Z, Rosenson RS, Staels B, Stock JK, Sy R, Wanner C Zambon A, Zimmet $P$. The residual risk reduction initiative: a call to action to reduce residual vascular risk in dyslipidaemic patient. Diab Vasc Dis Res 2008; 5: 319-335 